American Journal of Agricultural and Biological Sciences 6 (3): 332-338, 2011

ISSN 1557-4989

(C) 2011 Science Publications

\title{
Wheat Production and Economics
}

\author{
Elgilany Ahmed, Jamalludin Sulaiman \\ and Saidatulakmal Mohd \\ Department of Postgraduate Studies and Research, University Sains Malaysia, \\ School of Social Sciences, Pulau Pinang, Malaysia
}

\begin{abstract}
Problem statement: The crop in the irrigated scheme has faced by manifold problems contributed to low level of productivity and high cost of production of wheat. The crop is commonly produced under pump irrigation from the River Nile. In River Nile State (RNS), wheat is grown under the irrigated sector, the State is considered as a suitable environment for producing this crop. The study was conducted at Elzeidab irrigated scheme of RNS which is regarded as the oldest and biggest scheme belonging to the Ministry of Agriculture of RNS. Approach: Primary data was collected by using structured questionnaire for (70) randomly selected respondents. More than one technique used to assess economic aspects of the crop. Cobb-Douglas production function, descriptive statistics and partial budgeting have been employed to analyze the primary data. The study detected that the major socioeconomic characteristics of Elzeidab farmers were educated, the scheme tenants have had a cumulative experience in agriculture and average farm size is found to be small and the majority $50 \%$ of surveyed tenants in Elzeidab scheme were rented. The farming system of Elzeidab scheme is dominated by wheat production which counts to $25 \%$ of the farm land. The yield gab with the potential yield obtained by Agricultural Research Corporation (ARC) in the State amounts 66\%. The microfinance market in Elzeidab scheme is not well developed. Water charges in the scheme were high. About $53 \%$ of the annual running expenses were allocated for fuel that made irrigation costs to be the highest single component of production costs of the crop, while irrigation water cost was considered as the most agricultural constraint, this item was found to be as $19 \%$ of the total cost of production as the highest percentage overall the variable cost items. Results: The regression analysis revealed that the most factors affecting wheat productivity under the study were: the average of tenants' age, family labor, distance from home to field, hired labor, distance of farm to source of irrigation, number of irrigation, term of irrigation. Furthermore, the weakness of wheat production normally regards as a cost issue and lack of awareness wheat grower especially about wheat technical package. Conclusion: The study concluded that wheat production contribute significantly to farm sustainability and contribute to alleviation of malnutrition in the State. The actual production constraints restrict the sustainability of this important crop. The cooperation between international organizations and governmental institutions should tackle the hindrances of wheat production and achieve stability of wheat. There is a great potential for improvement the yield of the crop and an intervention of the State is needed to ease having the inputs of production especially irrigation water inputs.
\end{abstract}

Key words: Food security, wheat production, Agricultural Research Corporation (ARC), family labor, elzeidab public, public schemes, surveyed tenants, River Nile, field crop, food crop

\section{INTRODUCTION}

Wheat (Triticum aestivum) is a strategic crop in Sudan. It is Sudan's second most important cereal food crop in terms of consumption after sorghum. The wheat seed storage proteins are a major source of protein in the human diet, and are responsible for the properties of wheat doughs that allow a wide range of food products (Claudia et al., 2007). Over the past few years, wheat production, which is almost entirely irrigated, has been declining due to diminishing yields and soaring input costs. Since 1999, the Government liberalized the wheat production regime and removed all support programs. These moves have prompted many farmers

Corresponding Author: Elgilany Ahmed, Department of Postgraduate Studies and Research, University Sains Malaysia, School of Social Sciences, Pulau Pinang, Malaysia 
to drastically reduce wheat cultivation and/or switch to more lucrative cash crops, such as vegetables and oil seeds. Gezira, White Nile, New Halfa, River Nile and Northern States are the main suppliers for wheat crop. The overall area under wheat in this year (2005/06) is exceeded 290,360 feddan (122000 hectares).

The River Nile State is considered as one of the poor States in the country. Although the State with its relatively cooler weather and fertile alluvial soils, has a comparative advantages over other parts of the country in producing relatively high-value crops (wheat, faba beans, citruses, mangos, dates, certain spices and medical plants). Wheat is regarded as one of the major winter food crops in the State; the total area planted under wheat for season 2005/06 is estimated at 75,434 feddans. The State is consisted three types of schemes: private, cooperative and public schemes with different production relation systems. The optimum time for planting wheat is November and temperatures during this period remained cooler than average. In almost all wheat growing areas the bulk of the plantings occurred on time. The effectiveness of irrigation is determined by the availability and supply of fuel for pump irrigation and the degree of siltation in canals for larger schemes.

The public schemes are the important ones for growing winter crops due to their high acreage share and imply high number of tenants. Elzeidab public irrigated scheme is the oldest and the biggest one belonging to the State Ministry of Agriculture. It was established in 1904, the total area of the scheme is 22,000 feddans. Elzeidab scheme adopted the crop sharing arrangement based on cotton production since 1904 as an initiation policy after establishment. In 1939, the crop sharing was replaced by water rates based on the cost of pumping irrigation water. Later, in about 1952, the rates were increased on the base that the costs of factor- inputs in irrigation and administration had increased. Water rates have been introduced with the advance in perennial and vegetable crops. The delivery of the irrigation water for the scheme depends on pump irrigation system from the River Nile (RN). The $\mathrm{RN}$ is the main source of irrigation water for the scheme area, particularly for winter season which is considered as the principle season for State tenants, while the summer and autumn "demira" seasons are ranked after it due to some environmental aspects and that give advantages for winter crops and versa for other seasons crops.

Problem statements: The last three decades witnessed critical problems regarding wheat production. These constraints contribute to the low level and instability of wheat yield include poor practices of technical packages used by tenants, stress inflicted by the changing of environmental conditions especially temperature beside the widespread of different diseases, insects, pests, weeds and power failure that a companied by lack and high cost of fuel and spare parts to operate the pumps. Faki et al. (2004) summarized that the high cost of production coupled with low productivity and lack of a cheap source of power has made it difficult for the farmers to realize the full potential of the State. Further, development is considered by serious limitation on the two basic resources: land and water. Ahmed (2004) stated that, the irrigation water significantly affects the crop production in the State and the irrigated schemes in the River Nile State are suffered of irrigation shortage due to inadequate supply of irrigation inputs in proper time and at right prices.

\section{MATERIALS AND METHODS}

The study was carried out in 2006 at Elzeidab public irrigated scheme of RNS where wheat is commonly produced under pump irrigation mainly from the River Nile. The sample size for this study is 70 tenants, which formed about $2.3 \%$ of Elzeidab scheme tenants. The tenants were selected randomly from the scheme. The sample size was determined according to the level of the precision desired and availability of the resources in terms of cost, time and other relevant facilities. As precision could be a achieved, stratified random sampling based on convince and flexibilities with probabilities to size was used to determine the plausible size of the targeted groups in Elzeidab scheme of the RNS. Integrated analytical techniques comprising Cobb-Douglas production function, descriptive statistics and partial budgeting are used to illustrate wheat production and economics in area of the study.

\section{RESULTS AND DISCUSSION}

Starting with main socioeconomic indicators in the study area, the average age of surveyed tenants on Elzeidab scheme is found as 39.91 years, while the average family size of surveyed tenants ranges from 115 people. The surveyed tenants of Elzeidab scheme characterized by high cumulative of experience years estimated as 19.9 years. The average farm size of the scheme varies from 1- 28 feddan per farm household. The study found that the average distance from tenant's residence to farm of the surveyed tenants as $2.7 \mathrm{~km}$ and the majority of the tenants $85.7 \%$ of them are married. The level of education, at certain point, can influence the adoption of modern technologies and improve the farm system. The study found that all the surveyed 
tenants of Elzeidab are educated and all of them were male. The survey revealed that $74.3 \%$ were fully occupied with their tenancies and about $84.3 \%$ of their family members were shared on farm production with 2 persons. The research detects that the majority $50 \%$ of surveyed tenants in Elzeidab scheme were rented. The farming system of Elzeidab scheme is dominated by wheat production which counts to $25 \%$ of the farm land.

\section{Situation of wheat in dominant crop combination of} Elzeidab scheme: Information on the cultivated areas of agricultural products is as basic tools in preparing import-export policies, pricing agricultural products, planning agricultural developments and other relevant issues (Ashourloo et al., 2008). The winter seasonal crops of Elzeidab scheme occupy about 12000 fed of 16000 fed which is equal $67 \%$ of the total cultivated area of the scheme in season 2005/06. Wheat is regard as one of the important winter crops in the scheme crop rotation covering $25 \%$ of the total cultivated land, followed by $19 \%$ for sorghum and $14 \%$ for onion, while the lowest percentage $1 \%$ devoted for potato.

The other crops were ranked as 2, 2, 4, 5, 8, 8 and $12 \%$ achieved by spices, dry bean, maize, fodder, vegetables, chick pea and faba bean respectively, with absent of lentil crop area due to some technical production constraints. Figure 1 depicts that. The majority of these crops consisting wheat are cultivated as winter crops with exceptional cases for some crops that could produced in both winter and summer seasons namely: maize, fodder and vegetables. Furthermore, the sorghum crop usually sown at the end of summer season (September) to be harvested at the middle of the winter season (January). The harvested crops either for domestic consumption or/and as for earning cash.

Production cost of wheat: Cost recovery is an important reform strategy in agricultural advisory services. A number of different countries have contracted out advisory services to private providers or have diversified the funding of this activity (Ali et al., 2008). Production economics play a unique role in farm management (Doll and Orzem, 1992).

The dominant conception of production cost in the area of study is known as the cost of material inputs, labor force, services and the management used in producing a certain goods or/and crops. Many studies showed that the cost of production overall the RNS has leaded to the low profit. The high cost of production attributed to high cost of numerous of production inputs, but absolutely, the irrigation water cost is considered as the most agricultural constraint and that might refer to the high cost pumping water from the River Nile and this is justified strict allocation among the different crops grown. The coming elaboration of the survey results in Fig. 2 discerned the cost items as the sequence of the seasonal crop production operations.

The study detected that mainly about 13 cost components as mentioned in the above figure; they constitute the cost of production and they accounted SDD 70054.2 equal about US \$ 300. Irrigation cost component achieved the highest cost item as $19 \%$ of total production cost. The wheat growers in Elzeidab scheme pay the cost of this item as a fixed rate for the scheme administration at the end of the season.

Labour supply for wheat production: As known labour is regarded as one of the essential inputs, the survey pursued to assess this component. The research found that farm labour force in Elzeidab scheme comprises both family and hired labours according to the production stage, size of cultivated area, financial abilities of tenants and the type of the crop. The wheat grower tended to avoid hired labours to reduce the cost of production, but sometimes and for some production stages that require large number of labours force, they found themselves compelled to hire labour (s), such as for pre-sowing land cleaning, canal cleaning, plots preparation, weeding, pest control and harvesting stages.

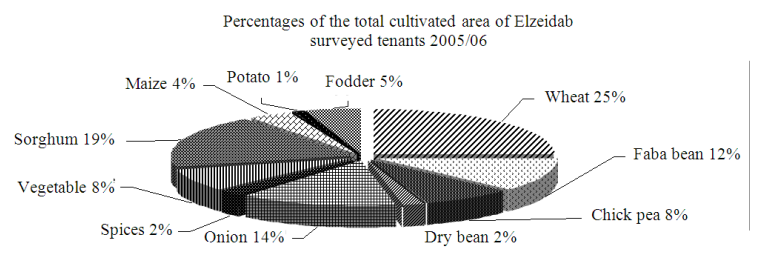

Fig. 1: Situation of wheat crop in dominant crop combination of Elzeidab scheme

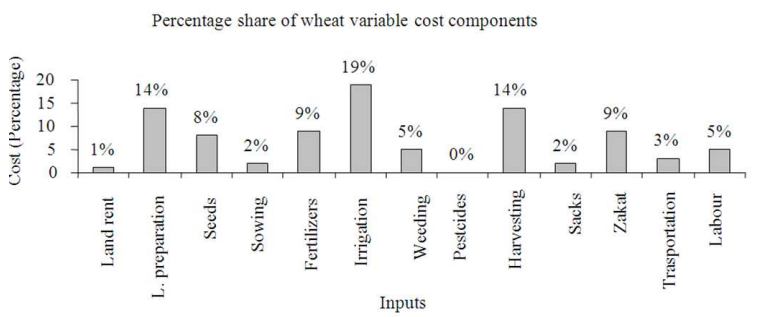

Fig. 2: Percentages share of wheat variable cost components in 2005/06 


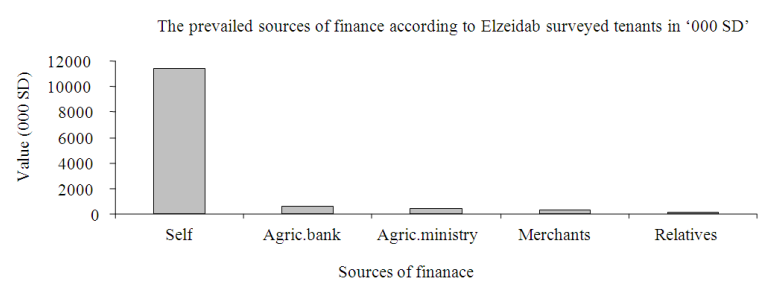

Fig. 3: Prevailed sources of finance in the area of the study

Table 1: Investigates gross margin analysis of wheat in Elzeidab scheme

\begin{tabular}{lr}
\hline Production cost (SDD/feddan) & 70054.2 \\
\hline Average yield (kg/feddan.) & 675.90 \\
Average price (SDD/kg) & 110.00 \\
Gross return (SDD/feddan.) & 74349.00 \\
Gross marginal revenue (SD/feddan.) & 4294.77 \\
\hline
\end{tabular}

Source: Author field survey (2006)

Table 2: Investigates gross margin revenues of some field crops in Elzeidab scheme, season 2005/2006 (SD/feddan)

\begin{tabular}{lr}
\hline Seasonal crops & Gross marginal revenue (SDD/feddan.) \\
\hline Wheat & 4294.77 \\
Faba bean & 8794.28 \\
Chickpea & 87749.24 \\
Dry bean & 97950.00 \\
Onions & 65538.40 \\
Sorghum & 36801.60 \\
Maize & 6831.31 \\
Potatoes & 32200.00 \\
\hline Source: Author field survey (2006)
\end{tabular}

Source: Author field survey (2006)

The surveyed tenants reported that two family members contributed in wheat production stages as family labours and the hired labour for the crop varies from stage to another. The study was estimated wheat' labour requirements as 15 man-days and it achieved low labour productivity of $45.06 \mathrm{~kg} / \mathrm{man}$-day.

Finance of wheat: The formal financial system provides only small parts of credit used by farmers. Therefore, most of farmers seek other informal sources of finance. Loans extended by friends and relatives, mostly without interest, constitute the non-commercial segment. In the commercial segment a range of people like traders, agricultural and professional money lenders operate (Ijami, 1994). The formal finance in the River Nile State usually comes from Agricultural Bank of Sudan and State Ministry of Agriculture. The form of finance is often in kind and some extend in cash, but considered insufficient to meet the actual cost requirements for farm operations. The study revealed that both of the formal sources of finance mentioned above provided means for only a small percentage of the total respondents; $1.4 \%$ of the total surveyed tenants. Figure 3 illustrates that $93 \%$ of Elzeidab scheme surveyed tenants have to depend on their own resources of about SDD 2379 for a farm, while the other informal financing sources represented $2.8 \%$ from village merchants (about SDD 170000) and $1.4 \%$ for relatives (SDD 50000).

Wheat productivity in area of the study: The profitability of adopting new irrigation technologies depends on the level of productivity improvement (Lin, 1994). Wheat yield achieved by Elzeidab surveyed tenants was generally low $675.90 \mathrm{~kg} / \mathrm{feddan}$ when compared by research yield reported by the Agricultural Research Corporation (ARC) which formed 2000 $\mathrm{kg} /$ feddan. Yield gap of $66 \%$ apply for wheat crop, indicated that much potential gap exists to increase the scheme's yield of wheat.

Analysis of wheat returns: The surveyed tenants reported that the production cost was less than the gross returns, in other words, the cash outflows was less than the cash inflow and there was a surplus of SDD 4294.77 Table 1 shows that. The gross margin equation was used to achieve this analysis. Gross margin in simple words, it is equal to gross income divided by net sales. Gross margin is a good indicator of how profitable a firm is at the most fundamental level. The general mathematical form for the gross margin analysis used to calculate the gross margin as follow:

$\mathrm{GM}=\mathrm{GR}-\mathrm{TVC}$

Where:

GM = Gross margin of each crop per feddan in SDD

$\mathrm{GR}=$ Gross revenue of each crop per feddan in SDD

$\mathrm{TVC}=$ Total variable cost per feddan in SDD

The research revealed that the gross margin for Elzeidab scheme for season 2005/06 was expressed in Sudanese Dinar (SDD) as discerned in Table 1.

Table 1 also investigates that, although the gross margin of wheat was found to be positive, but it was low as feedback for its average cultivated area if we consider the opportunity chance of the wheat area and its remaining period within the rotation at both level farm and scheme. The RNS experienced increasing input prices in the last decade and that might explain the high cost of wheat production. According to this fact, wheat could be assessed as infeasible crop unless improvements are made.

Table 2 shows gross marginal revenues for numerous seasonal crops in Elzeidab were exceeded the gross margin of wheat indicating their highly profitability. 
Am. J. Agri. \& Biol. Sci., 6 (3): 332-338, 2011

Table 3: Wheat regression equation results

\begin{tabular}{|c|c|c|c|c|}
\hline Variables & $\begin{array}{l}\text { Standard } \\
\text { Coefficients }\end{array}$ & $\begin{array}{l}\mathrm{t}- \\
\text { errors }\end{array}$ & $\begin{array}{l}\text { Level } \\
\text { values }\end{array}$ & Significant $(*)$ \\
\hline Intercept & -13.482 & 6.220 & -3.169 & $*$ \\
\hline Age -0.264 & 0.629 & -2.700 & * & \\
\hline Family labours (man-day/fed) & 0.400 & 0.694 & 4.013 & $* *$ \\
\hline Hired labours (man-day/fed) & 0.942 & 0.509 & 5.303 & $* * *$ \\
\hline Home to field $(\mathrm{km})$ & 1.120 & 0.929 & 8.096 & $* * *$ \\
\hline Farm to source of irrigation $(\mathrm{km})$ & -0.819 & 0.000 & -7.903 & $* * *$ \\
\hline No. of irrigation (per season) & 0.421 & 0.419 & 2.533 & * \\
\hline Term of irrigation (hour/fed) & -1.446 & 0.765 & -5.875 & $* * *$ \\
\hline
\end{tabular}

Source: Computed from the field survey data, 2006; R-square $=0.93$ Adjusted R-square $=0.88 ;$ F-value $=17.87 ; *:=$ Significant at $90 \%$ level of probability; $* *=$ Significant at $95 \%$ level of probability; $* * *$ : Significant at $99 \%$ level of probability

Wheat regression results: Analysis of efficiency of resource allocation can be accomplished by estimating input response or production functions for various crops and examining resource use through production economics analysis. The data were statistically fit to several algebraic forms of production functions, a few of which were the linear model, the CobbDouglas, the Quadratic and the Cubic forms were used for this purpose (Worku, 1971). Instead a frequently used method for estimation is the CobbDouglas approach due to its ease of estimation and interpretation (Lin, 1994).

The model for the implemented study is based on Cobb- Douglas production function using the primary data of the field survey 2006 and hence, it was analyzed by using the software program SPSS. The model used to satisfy some of the specific aims of the research as far as the factors affecting WUE of the seasonal crops of Elzeidab scheme are concerned. The model undertook the wheat crop as a case for the seasonal crops due to it is biggest area share and it was considered the productivity of wheat crop (kg/fed) for season 2005/2006 as dependent variable, while the average of tenants' age, family labours (man-day/fed), distance from home to field $(\mathrm{km})$, hired labours (man-day/fed), distance of farm to source of irrigation $(\mathrm{km})$, number of irrigation (per season), term of irrigation (hour/fed).

All the variables have the expected correct signs with their coefficients passing the t-test at different significant levels. The F-statistics of 15.11 is significant. The model is specified in a linear-linear form, hence, the coefficients of the variables represent the corresponding elastic ties and that indicate the relative change in water applied to the wheat crops $\left(\mathrm{m}^{3} / \mathrm{fed}\right)$ relative to relative change in independent variables. The variables included in the model were the average of tenants' age, family labours (man-day/fed), distance from home to field $(\mathrm{km})$, hired labours (manday/fed), distance of farm to source of irrigation $(\mathrm{km})$, number of irrigation (per season), term of irrigation (hour/fed), were found to be significantly at different levels as illustrated in Table 3.
Age of tenants: The age of tenants has got coefficient of -0.26 which is significant at $90 \%$ level of significance. Since this coefficient in represent the elasticity which indicates the change in the wheat productivity in season $2005 / 06$, a one percent increase on tenants' age will decrease the yield by $0.26 \%$. The study revealed that the ages of more than $68 \%$ of Elzeidab tenant were above 30 years. As known younger tenants adopted new ideas and technologies more rapidly than older ones.

Hired and Family labours: The numbers of hired and family labours have got coefficients of 0.94 and 0.40 which significant at 99 and $95 \%$, respectively. The coefficients of these independent variables in the model represent the elasticity which explains the change in wheat yield to the change in the hired and family labours. The elasticity form represents: a relative increase of $1 \%$ in hired and family labour will cause a relative increase of 0.94 and $0.40 \%$ in yield of wheat, respectively. The family labour considered as one the main labour force farm operation and their share will contribute positively for farm production and income, while the hired labour considered as second option for Elzeidab farmers. The decreasing of labour supply coupled with high wages led most of the farmers to avoid item of hiring labour, this explain why farmers ignore some of manual agricultural practices, moreover, due to their poor financial resources, some of the family members left agricultural occupation to other jobs and also the absence of financial sources.

Home to field distance: Home to field variable has got coefficient of 1.120 for wheat yield in 2005/2006 season which is significant at $99 \%$ level of significance and that statistically means the change in the wheat productivity in season 2005/06, a one percent increase on the distance of home to field will increase the yield by $1.120 \%$. This interpretation investigates the strong relationship between distance and farm management, however, as a fact that the management should improve according to the term devoted for the farm management. The study revealed that average distance from the tenants residences' to their farms ranged between $2-20 \mathrm{~km}$ to be crossed on food or by animals as primitive means, hence, the tenants might spend a long time in their fields to a void movement and that will save their time and efforts.

Distance from a farm to irrigation sources: The coefficient for the distance from source of irrigation to a farm was found as 0.819 of wheat yield, which is significant at $99 \%$ level of significance. The coefficient 
represents the elasticity of the distance from source of irrigation to a farm variables show the change in the wheat productivity in season 2005/06; one percent increase on this variable will decrease the yield by $0.819 \%$. Numerous researches revealed that the design of surface irrigation net in most of the developing countries characterized by inadequate of irrigation water distribution particularly at that tail-canal. As a technical fact, increasing of distance from source of irrigation to a farm will ensuing increasing of irrigation water loses due to the water percolation and evaporation. The age of the existent irrigation system in Elzeidab scheme exceed 100 years and the partial rehabilitation constructions were done from time to time which are not sufficient to bridge the scheme to the efficient condition.

Number of irrigations: The number of irrigation variable of wheat in 2005/06 season has got coefficient of 0.42 which is significant at $90 \%$ level of significance. This is elasticity form: a relative increase of $1 \%$ in number of irrigation will cause a relative increase of $0.42 \%$ in yield of wheat. Numerous previous studies revealed that the most agricultural constraint in Northern Sudan is shortage of irrigation. (Saeed, 1988; Salih, 1996). All of them found that irrigation water significantly affect the crop production in Northern Sudan. The majority of the studies mentioned that the irrigation shortage may be attributed to inadequate supply of irrigation inputs such as fuel, spare parts, labor and their unavailability in proper time and at right prices for public and private sector. The impression of readers for this analysis might feel that there is conflict between actual quantities of applied water and the water shortage ensuing from the number of irrigation, but substantially, this confirm there is inefficiency of irrigation water use due to the misuse of the water by scheme management and the tenants at the field level.

Term of irrigation: The term of watering per hour/fed has got coefficients of -1.446 which is significant at 99\%. Since this coefficient in represent the elasticity which indicates the change in wheat productivity in season 2005/06, a one percent increase on the term of watering per hour/fed will decrease the wheat productivity by $1.446 \%$. The research detected that Elzeidab surveyed tenants over-irrigated their seasonal crops entirely and economically, this misuse of irrigation water led to waste water resources and technically will effects soil efficiency (i.e., salinity, decreasing air portion of soil) and plants (i.e., lodging) and that to low productivity.
Conclusion of the regression analysis: The regression analysis revealed the most factors affecting wheat productivity in River Nile State in season 2005/2006 were: the average of tenants' age, family labour (manday/fed), distance from home to field $(\mathrm{km})$, hired labour (man-day/fed), distance of farm to source of irrigation $(\mathrm{km})$, number of irrigation (per season), term of irrigation (hour/fed), were found to be significantly at different levels as illustrated in Table 3.

\section{CONCLUSION}

This study explore some of the findings of the field survey for Elzeidab area in RNS and it described the wheat production activities situation and conclusion drawn obtained from numerous analytical tools as follow: (1) The farming system of Elzeidab scheme is dominated by wheat production which counts to $25 \%$ of the farm land. (2)The yields of wheat crop in Elzeidab scheme were found to be lower when compared with the average yield reported by ARTC. (3)Water charges for Elzeidab public irrigated scheme regarded as a burden for wheat grower. (5)The research found that the irrigation cost item was found to be as $19 \%$ of the total cost of production as the highest percentage overall the variable cost items. (6)The costs of irrigation, land preparation and harvesting are the highest cost items in the process of wheat production. (7)The unfavorable climatic conditions, poor cultural practices and shortage of irrigation are the most important factors lowering the yield of the crop. (8) The unavailability of formal finance and limited informal finance as well as high cost of wheat production are usually decreasing farmers' returns.

Accordingly the study proposed the following recommendations:

- Because irrigation water is the main constraint facing wheat production in the studyarea due to the high input cost, intervention is needed to ease having this inputs either by subsidizing it or providing means of credit to enable farmers to keep their pumps working

- The study unveils the low value of the wheat crop particularly which is as strategic crop, so that it should be encouraged to secure food. The encouragement policies can imply reducing the cost of production or by incentive the wheat growers of the scheme by buying their products at satisfying prices

- Limited required inputs with a reasonable or subsidized prices as well as intensive role of extension are urgently needed to help wheat farmers to trace the recommended package 
- Improving finance institutions will enable the tenants to improve their resources use and significantly increase their farm returns

\section{REFERENCES}

Ahmed, E.A., 2004. Economics of Faba bean Production and Marketing in River Nile State (A Case Study Elddamer District). M.Sc. Thesis, University of Khartoum, pp: 103. http://agris.fao.org/agris-

search/search/display.do?f=2005/SD/SD0503.xml; SD2005000028

Ali, A., A. Morteza, S.F. Hossain and A. Amir, 2008. An assessment of farmers willingness to pay for wheat consultant engineers project: In Iran. Am. J. Agric. Biol. Sci., 3: 706-711. DOI: 10.3844/ajabssp.2008.706.711

Ashourloo, D., A.A. Matkan, H. Aghighi, A. Hosseni and A. Gholampour et al., 2008. Irrigated and nonirrigated wheat classification based on cultivation calendar by HIS algorithm. Am. J. Agric. Biol. Sci., 3: 602-609. ISSN: 1557-4989

Claudia, G., P. Yves and G. Jacques, 2007. Expression of thioredoxin-fusion proteins of a-gliadin, $\mathrm{g}$ gliadin and low molecular weight glutenin, from wheat endosperm and their domains in enterobacteria. Am. J. Infect. Dis., 3: 84-91. DOI: 10.3844/ajidsp.2007.84.91
Doll, J.P., and F. Orazem, 1992. Production Economics: Theory with Applications. 2nd Edn., Krieger Publishing Company, ISBN-10: 0894647695, pp: 470.

Faki, H., A. Elsir and M. Idris, 2004. Irrigated Benchmark Site Project for Sudan. Plan of work presented for Agricultural Research Corporation (ARC). Wad Madani, Sudan.

Ijami, A.A.M., 1994. Efficiency and equity Effects of Market Access on Agricultural productivity in Sudan: A Case Study Small Holder Along the river Nile, north of Khartoum ... zur internationalen Agrarentwicklung). Koster, ISBN-13: 9783895740282, pp: 1999.

Lin, J.Y., 1994. Impact of hybrid rice on input demand and productivity. Agric. Syst., 10: 153-164. DOI: 10.1016/0169-5150(94)90004-3

Saeed, M., 1988. The economics of crop production in the Northern Province: A Case Study of Selaim Basin. Unpublished M.Sc. Thesis, University of Khartoum.

Salih, S.H., 1996. Production and Improvement of Cool - Season Food Legume in Sudan. 1st Edn., ICARDA, ISBN: 9291270423, pp: 250.

Worku, D., 1971. The Economics of Water Use: An inquiry Into the Economics Behavior of Farmers in West Pakistan. PhD Thesis, Colorado State University, Fort Collins, Colorado, pp: 162. http://library.wur.nl/WebQuery/clc/264914 